\title{
Central and peripheral interleukin-1 $\beta$ and interleukin-1 receptor I expression and their role in the acute stress response of common carp, Cyprinus carpio L.
}

\author{
Juriaan R Metz ${ }^{\mathbf{1}}$, Mark O Huising ${ }^{1,2}$, Karin Leon², B M Lidy Verburg-van Kemenade ${ }^{2}$ and Gert Flik \\ ${ }^{1}$ Department Organismal Animal Physiology, Faculty of Science, Radboud University Nijmegen, Toernooiveld 1, 6525 ED Nijmegen, The Netherlands \\ ${ }^{2}$ Cell Biology and Immunology Group, Wageningen University, Marijkeweg 40, 6709 PG Wageningen, The Netherlands \\ (Requests for offprints should be addressed to G Flik; Email: g.flik@science.ru.nl)
}

\begin{abstract}
In fish, the hypothalamus-pituitary-interrenal axis (HPIaxis), the equivalent of the hypothalamus-pituitary-adrenal axis (HPA-axis) in mammals, is activated during stress and leads to production and release of cortisol by the interregnal cells in the head kidney. In mammals, the cytokine interleukin-1 $\beta$ (IL-1 $\beta$ ) takes a key position in the innate immune and inflammatory responses and influences the HPA-axis. In fish, studies that address the effects of cytokines on HPI-axis activation are limited. We quantitatively assessed expression of IL-1 $\beta$ and its receptor, IL-1RI (the latter was cloned and sequenced), in an acute restraint stress paradigm in common carp, Cyprinus carpio. We also considered expression of the pituitary hormones prolactin (PRL) and GH that have been shown to be structurally related to cytokines and have immunomodulatory actions. Pituitary PRL expression increased fourfold during stress; GH mRNA levels were

unaffected. Following restraint, hypothalamic IL-1 $\beta$ expression was upregulated; in head kidney and pituitary pars intermedia, IL-1RI expression significantly increased. We suggest that during acute stress IL- $1 \beta$ signalling in the HPI-axis becomes more sensitive, since both ligand and receptor expressions are enhanced. In vitro, recombinant carp IL-1 $\beta$ stimulates release of $\alpha-\mathrm{MSH}$ and $\mathrm{N}-\mathrm{Ac} \beta$-endorphin from the pituitary gland. This observation concurs with increased in vivo plasma levels of $\alpha-\mathrm{MSH}$ and $\mathrm{N}-\mathrm{Ac}$ $\beta$-endorphin following restraint. Our findings combined lead us to conclude that IL-1 $\beta$ affects the activity of the HPI-axis and, in turn, expression profiles of genes encoding IL-1 $\beta$ and its receptor are modified during acute stress. Our study provides convincing evidence for bi-directional communication of the HPI-axis and the immune system in fish.

Journal of Endocrinology (2006) 191, 25-35
\end{abstract}

\section{Introduction}

In fish, neuroendocrine factors modulate the activity of the immune system, and conversely, signals from the immune system affect neuroendocrine activity (Harris \& Bird 2000, Engelsma et al. 2002, Yada \& Nakanishi 2002). These mutual interactions are increasingly investigated, profiting from the application of the ever increasing resolution of molecular biological techniques and publicly available databases of fish genome-sequencing projects (Huising et al. 2003a, 2004a). It is generally accepted that our understanding of mechanisms, which underlie immune-stress relations will improve our insights in health and welfare of fish in production systems, since stress is a potential factor causing increased susceptibility of fish to pathogens.

The hypothalamus-pituitary-interrenal axis (HPI-axis), the piscine equivalent of the hypothalamus-pituitary-adrenal axis (HPA-axis) in mammals, is activated during stress (Wendelaar Bonga 1997) and is considered the most important neuroendocrine modulatory system of the immune system. Corticotrophin-releasing hormone (CRH), released

from the nucleus preopticus (NPO) of the hypothalamus (Huising et al. 2004b), stimulates synthesis of pro-opiomelanocortin (POMC) in the pituitary gland (Metz et al. 2004). POMC is the precursor for adrenocorticotrophic hormone $(\mathrm{ACTH}), \boldsymbol{\alpha}$-melanocyte-stimulating hormone $(\boldsymbol{\alpha}-\mathrm{MSH})$ and $\beta$-endorphin. These peptides are released upon stimulation by CRH (Tran et al. 1990, Van den Burg et al. 2001, Metz et al. 2004) from the pars distalis (PD; ACTH) and pars intermedia (PI; $\alpha-\mathrm{MSH}$ and $\beta$-endorphin). In the interrenal cells of the head kidney, ACTH stimulates the synthesis and release of cortisol, which in turn secures energy redistribution in the body to overcome the stressor (Wendelaar Bonga 1997, Gallo \& Civinini 2003). This is brought about by gluconeogenesis in the liver and withdrawal of energy from physiological systems not directly influenced by the stressor, including the immune system, to the benefit of systems whose activity needs to be intensified. In particular, immunosuppressive effects of cortisol include a reduced number of circulating lymphocytes, inhibited lymphocyte proliferation and decreased numbers of antibody-producing cells and lower antibody production (reviewed by Harris \& Bird 2000). 
In mammals, a number of immune cells were shown to produce $\mathrm{CRH}, \mathrm{ACTH}$ and $\beta$-endorphin (Lyons \& Blalock 1997, Turnbull \& Rivier 1999, Baigent 2001). A few studies report on production of these hormones by leukocytes of fish as well: POMC mRNA has been detected in goldfish phagocytes (Ottaviani et al. 1995), CRH-immunoreactivity is reported in the goldfish thymus (Ottaviani et al. 1998) and catfish leukocytes were shown to produce ACTH (Arnold \& Rice 2000). The interaction of pituitary hormones with the immune system is not restricted to POMC-derived peptides: in mammals, as well as fish, it has been documented that growth hormone $(\mathrm{GH})$ and prolactin $(\mathrm{PRL})$ enhance various functions of immune cells, including phagocytic activity, immunoglobulin $\mathrm{M}(\mathrm{IgM})$ production and mitotic activity of leukocytes (Harris \& Bird 2000, Yada et al. 2002, 2004). Indeed, PRL and GH are structurally related to a number of cytokines (Sprang \& Bazan 1993) and are expressed in several lymphoid tissues, including head kidney (Yada et al. 2002). We, therefore, also considered expression of these two hormones in the present study.

In mammals, communication of immune-derived signals with the HPA-axis occurs via interleukin-1 $\beta$ (IL-1 $\beta$ ) and to a lesser extent IL-6 and tumour necrosis factor- $\alpha$ (TNF- $\alpha$ ). These cytokines have been shown to influence neuroendocrine activity in mammals, resulting in increased activity of ACTH and cortisol during infection, inflammation and stress (Mastorakis et al. 1993, Shintani et al. 1995, Dunn 2000). In fish, studies that address effects of cytokines on HPI-axis activation are scarce, but it has been suggested that IL-1 $\beta$ activates the HPI-axis (Verburg-van Kemenade et al. 2001, Holland et al. 2002), as is the case in mammals.

IL-1 $\beta$ mediates its effects through the cell surface receptor type I (IL-1RI), which forms a receptor complex with recruit IL-1R accessory protein (IL-1Rap; Casadio et al. 2001, Dunne \& O'Neill 2003, Subramaniam et al. 2004). IL-1RI contains extracellular immunoglobulin domains, a short transmembrane region and an intracellular Toll/IL1-receptor (TIR) domain (Sims 2002). To date, fish IL-1RI has been identified in rainbow trout (Holland et al. 2000), Atlantic salmon (Subramaniam et al. 2002), pufferfish and zebrafish (Huising et al. 2004a). Following in vivo lipopolysaccharide (LPS) treatment, expression of IL-1RI is induced in liver, head kidney, spleen and gills (Subramaniam et al. 2002).

In this study, we investigated the neuroendocrineimmune interactions in common carp, Cyprinus carpio L. We cloned and sequenced the carp orthologue of the IL-1RI to be able to characterise cells and tissues that have the potential to respond to IL-1 $\beta$. We quantitatively assessed the expression of IL-1 $\beta$, IL1-RI, GH and PRL in hypothalamus, pituitary gland and head kidney of control and stressed fish. Finally, we present in vitro evidence that IL-1 $\beta$ targets melanotrope cells in the pituitary gland to release $\alpha-\mathrm{MSH}$ and acetylated $\beta$-endorphin. The physiological role of this interaction between the immune and stress responses will be discussed.

\section{Materials and Methods}

\section{Animals}

Common carp (C. carpio L.) of the $\mathrm{R} 3 \times \mathrm{R} 8$ strain (Huising et al. 2004b), weighing around $50 \mathrm{~g}$, were produced by the De Haar Vissen facility in Wageningen, The Netherlands. Fish were reared in the Nijmegen facilities in 2501 tanks at $22^{\circ} \mathrm{C}$. Fish were fed commercial fish food (Trouvit, Trouw, Putten, The Netherlands) at a ration of $1.5 \%$ of the body weight per day. Prior to sampling, fish were anaesthetised in $0 \cdot 1 \%(\mathrm{v} / \mathrm{v})$ 2-phenoxyethanol (Sigma). Experimental protocols were according to Dutch legislation and approved by the ethical committee of the Radboud University Nijmegen.

\section{Restraint stress experiment}

Groups of eight carp were transferred from stock tanks to experimental tanks and acclimatised for at least 4 weeks. On the day of the experiment, eight fish at a time were confined in a net in their own aquarium. Controls were left undisturbed in another tank. After $24 \mathrm{~h}$, fish were quickly caught, anaesthetised and sampled. Blood was taken by puncture of the caudal vessels with heparin as an antiagglutinant. Plasma was separated from blood cells by centrifugation $\left(10000 \mathrm{~g}, 10 \mathrm{~min}, 4^{\circ} \mathrm{C}\right)$.

Brains, pituitary glands and head kidneys were collected. From the brains, a small cube of tissue containing the NPO was dissected. In carp, the NPO is situated rostrodorsally from the optic nerve (Metz et al. 2004). Dissection was performed in a standardised way by four cuts, using the optic nerve as a landmark (Fig. 1). From the pituitary glands, PD and PI were carefully separated. Under a stereomicroscope, pituitary PD (brightly white tissue) and PI (opaque) can easily be distinguished by colour. To verify proper separation, we homogenised three pituitary PDs and PIs in $0.01 \mathrm{M} \mathrm{HCl}$. After centrifugation $\left(15000 \mathrm{~g}, 10 \mathrm{~min}, 4^{\circ} \mathrm{C}\right)$ to remove

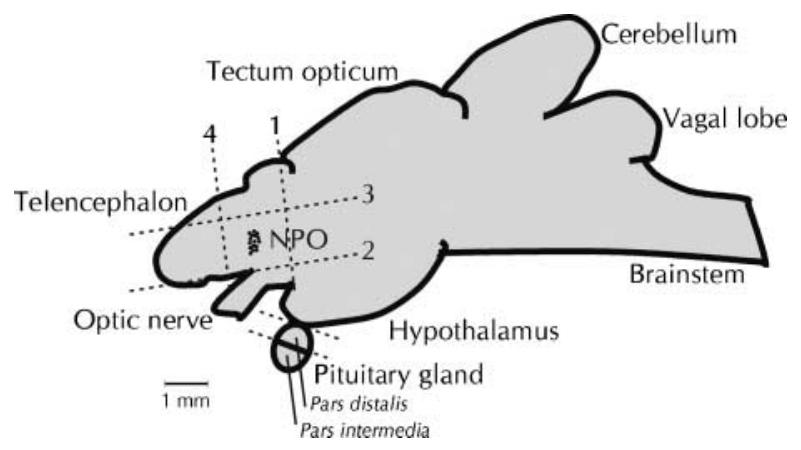

Figure 1 Sagittal overview of the carp brain showing the dissection procedure of the NPO and pituitary PD and PI. Dissection of the NPO is realised by four consecutive cuts (numbers 1-4 in the figure), utilising the bases of the optic nerve and telencephalon as landmarks. In general, the pituitary gland detaches when the brain is being dissected. Separation of PD and PI, the colours of which are different, is carried out under a stereomicroscope. 
cellular debris, supernatants were analysed for $\alpha-\mathrm{MSH}$ and ACTH by RIAs (Metz et al. 2004). Neither $\alpha-\mathrm{MSH}$ immunoreactivity was detected in the PD, nor was ACTH detectable in the PI (data not shown).

\section{Quantitative expression}

Expression of IL-1 $\beta$, IL1-RI, GH and PRL in the collected tissues was assessed by quantitative reverse transcriptase (RT)PCR. Total RNA $(1 \mu \mathrm{g})$, isolated from fresh tissues with TRIzol reagent (Invitrogen) according to the manufacturer's instructions, was incubated with $1 \mathrm{U}$ DNase I (Invitrogen) for $15 \mathrm{~min}$ at room temperature to ensure complete removal of trace genomic DNA. EDTA $(1 \mu \mathrm{l}$ of $25 \mathrm{mM})$ was added and the sample was incubated for $10 \mathrm{~min}$ at $65^{\circ} \mathrm{C}$ to inactivate DNase and simultaneously linearise the RNA. First-strand cDNA was synthesised for $1 \mathrm{~h}$ at $37^{\circ} \mathrm{C}$ in a $20 \mu \mathrm{l}$ reaction mixture, containing the RNA, $300 \mathrm{ng}$ random hexamers, $0.5 \mathrm{mM}$ dNTPs, $10 \mathrm{U}$ RNase inhibitor (Invitrogen), $10 \mathrm{mM}$ dithiothreitol and $200 \mathrm{U}$ superscript II reverse transcriptase (Invitrogen).

For quantitative PCR analysis, $5 \mu \mathrm{l}$ of five times diluted RT mix were used as template in $25 \mu \mathrm{l}$ amplification mixture, containing 12.5 $\mu \mathrm{l}$ SYBR Green Master Mix (Applied Biosystems Benelux, Nieuwerkerk aan den IJssel, The Netherlands) and $3.75 \mu$ of each primer (final concentration $300 \mathrm{nM})$. The primer sets were designed using Primer Express 2.0 Software (Applied Biosystems), synthesised by Biolegio (Malden, The Netherlands) and are shown in Table 1. After an initial denaturation step at $95^{\circ} \mathrm{C}$ for $10 \mathrm{~min}$, a real-time PCR of 40 cycles was performed (GeneAmp 5700, Applied Biosystems), each cycle consisting of $15 \mathrm{~s}$ denaturation at $95^{\circ} \mathrm{C}$ and 1 -min annealing and extension at $60{ }^{\circ} \mathrm{C}$. Cycle threshold $\left(C_{\mathrm{T}}\right)$ values were determined and expression was calculated as a percentage of the housekeeping genes $\beta$-actin or $40 \mathrm{~S}\left(\Delta \Delta C_{\mathrm{T}}\right.$; Pfaffl 2001). Results were confirmed to be similar following standardisation to either gene. For clarity, only results that are standardised for $40 \mathrm{~S}$ expression are presented here.

\section{Cloning and sequencing}

Two oligonucleotide primers were designed based on a predicted zebrafish IL-1RI sequence (IL-1RI.fw1, 5' (-GCA GAA AAG GCA ATG ATA CIT GG-3'; IL-1RI.rv2, $5^{\prime}$-TAG GCC AGA ACC AGA TCA AC-3 ${ }^{\prime}$ ). PCR with these primers on a $\lambda Z A P$ cDNA library of PMA-activated carp head kidney macrophages yielded a $745 \mathrm{bp}$ product. PCRs were performed using $0.5 \mu \mathrm{l}$ Taq DNA polymerase (Goldstar; Eurogentec, Seraing, Belgium) supplemented with $1.5 \mathrm{mM} \mathrm{MgCl}_{2}, 200 \mu \mathrm{M}$ dNTPs and $400 \mathrm{nM}$ of each primer in a final volume of $25 \mu \mathrm{l}$. Cycling conditions were $94^{\circ} \mathrm{C}$ for $2 \mathrm{~min} ; 35$ cycles of $94^{\circ} \mathrm{C}$ for $30 \mathrm{~s}, 55^{\circ} \mathrm{C}$ for $30 \mathrm{~s}$ and $72{ }^{\circ} \mathrm{C}$ for $1 \mathrm{~min}$, followed by a final extension step of $72{ }^{\circ} \mathrm{C}$ for $10 \mathrm{~min}$. PCR products were ligated and cloned into JM-109 cells using the pGEM-T-easy kit (Promega) according to the manufacturer's protocol. Sequences were determined from both strands using T7 and SP6 primers and were carried out using the ABI Prism BigDye Terminator Cycle Sequencing Ready Reaction kit (Applied Biosystems). The rest of the sequence was obtained in a rapid amplification of cDNA ends (RACE) approach (GeneRacer, Invitrogen) according to the manufacturer's instructions.

\section{Phylogenetic tree construction}

Multiple sequence alignments were carried out with the ClustalW program at http://www.ebi.ac.uk/clustalw/. A phylogenetic tree was constructed on the basis of amino acid difference (p-distance) by the neighbour-joining method (Saitou \& Nei 1987) with MEGA version 2.1 (Kumar et al. 2001). Reliability of the tree was assessed by bootstrapping, using 1000 bootstrap replications.

\section{Cell isolation and in vitro stimulation}

Both carp head kidneys were removed and passed through a $50 \mu \mathrm{m}$ nylon mesh with carp RPMI (cRPMI; RPMI 1640; Gibco) containing $10 \mathrm{U} / \mathrm{ml}$ heparin (Leo Pharmaceutical Products, Weesp, The Netherlands) and adjusted to carp

Table 1 Sequences of primer sets used in real-time quantitative PCR

\begin{tabular}{|c|c|c|c|}
\hline & Primer & Sequence & Accession no. \\
\hline \multicolumn{4}{|l|}{ Gene } \\
\hline \multirow[t]{2}{*}{$I L-1 \beta$} & qIL-1b.fw & CTGGAGCAATGCAATACAAAGTTC & CCA245635 \\
\hline & qlL-1b.rv & CAAGGTAGAGGTTGCTGTTGGAA & \\
\hline \multirow[t]{2}{*}{$I L-1 R I$} & qIL-1RI.fW & ACGCCACCAAGAGCCTTTTA & AJ843873 \\
\hline & qIL-1RI.rv & GCAGCCCATATTTGGTCAGA & \\
\hline \multirow[t]{2}{*}{$P R L$} & qPRL.fw & CATCAATGGTGTCGGTCTGA & X52881 \\
\hline & qPRL.rv & TGAAGAGAGGAAGTGTGGCA & \\
\hline \multirow[t]{2}{*}{$\mathrm{GH}$} & qGH.fw & ССААССАGСТСАСТGАGAА & X13670 \\
\hline & qGH.rv & ССTGGATGAGCACACTGAT & \\
\hline \multirow[t]{2}{*}{$\beta$-actin } & qACT.fw & CAACAGGGAAAAGATGACACAGATC & CYIACTBA \\
\hline & qACT.rv & GGGACAGCACAGCCTGGAT & \\
\hline \multirow[t]{2}{*}{$40 S$} & q40S.fw & CCGTGGGTGACATCGTTACA & AB012087 \\
\hline & q40S.rv & TCAGGACATTGAACCTCACTGTCT & \\
\hline
\end{tabular}


osmolarity $(270 \mathrm{mOsm} / \mathrm{kg})$. The cell suspension was layered on discontinuous Percoll (Amersham Pharmacia Biotech AB) gradient $\left(1 \cdot 02,1 \cdot 07\right.$ and $\left.1 \cdot 083 \mathrm{~g} / \mathrm{cm}^{3}\right)$. Following centrifugation (25 min at $800 \mathrm{~g}$ with brake disengaged) cells at the $1 \cdot 07 \mathrm{~g} / \mathrm{cm}^{3}$ interface (macrophage-enriched leukocytes) were collected and washed. Cells were suspended in cRPMI, supplemented with $0 \cdot 5 \%$ pooled carp serum, $1 \%$ L-glutamine (Merck), $200 \mathrm{nM} \beta$-mercaptoethanol (Bio-rad), $1 \%$ penicillin $G$ (Sigma) and $1 \%$ streptomycin sulphate (Sigma). Cells were seeded in a $24-$ well cell culture plate at a concentration of $4.5 \times 10^{6}$ cells $/ \mathrm{ml}$ in a volume of $400 \mu \mathrm{l}$ per well $\left(1.8 \times 10^{6}\right.$ cells/well $)$ and cultured overnight at $27^{\circ} \mathrm{C}, 5 \% \mathrm{CO}_{2}$. Following overnight culture, cells were stimulated for $4 \mathrm{~h}$ with $20 \mu \mathrm{g} / \mathrm{ml}$ concanavalin A (ConA; Sigma), $50 \mu \mathrm{g} / \mathrm{ml}$ lipopolysaccharide (LPS; Escherichia coli, Sigma) or $0 \cdot 1 \mu \mathrm{g} / \mathrm{ml}$ phorbol 12 -myristate 13 -acetate (PMA; Sigma). Following in vitro stimulation, cells were harvested and total RNA was isolated with the RNeasy Mini Kit (Qiagen), according to the manufacturer's instructions.

\section{In vitro superfusion}

Freshly isolated pituitary PI and head kidneys were placed on a cheese-cloth filter in a superfusion chamber. Tissues were superfused with carbogen-saturated 0.015 M HEPES/Trisbuffered medium $(\mathrm{pH}=7 \cdot 38)$, containing $128 \mathrm{mM} \mathrm{NaCl}$, $2 \mathrm{mM} \mathrm{KCl}, 2 \mathrm{mM} \mathrm{CaCl} \cdot 2 \mathrm{H}_{2} \mathrm{O}, 0 \cdot 25 \%$ (w/v) glucose, $0 \cdot 03 \%(\mathrm{w} / \mathrm{v})$ BSA and $0.1 \mathrm{mM}$ ascorbic acid. The flow was set at $30 \mu \mathrm{l} / \mathrm{min}$. After $150 \mathrm{~min}$, when hormonal release had reached an apparent steady state, the medium was supplemented with $100 \mathrm{ng} / \mathrm{ml}(5 \cdot 3 \mathrm{nM})$ recombinant carp IL-1 $\beta$ (Yin \& Kwang 2000) for $10 \mathrm{~min}$. At $t=180 \mathrm{~min}$, a $10-\mathrm{min}$ control pulse was applied: pituitary glands were stimulated with $1 \times 10^{-7} \mathrm{M}$ thyrotrophin-releasing hormone (TRH; Biotrend, Köln, Germany) and head kidneys were stimulated with $5 \times 10^{-8} \mathrm{M}$ human ACTH (Sigma). Five- or fifteenminute fractions were collected, immediately stored at $-20{ }^{\circ} \mathrm{C}$ and analysed for $\alpha$-MSH, N-Ac $\beta$-endorphin and cortisol by RIA.

\section{RIAs for $\alpha$-MSH, $N$-Ac $\beta$-endorphin and cortisol}

$\alpha-\mathrm{MSH}, \mathrm{N}-\mathrm{Ac} \beta$-endorphin were measured by RIA with antibodies against synthetic human mono-Ac $\alpha$-MSH (Van Zoest et al. 1989) and salmon N-Ac $\beta$-endorphin (Takahashi et al. 1984) respectively, according to the method described earlier (Van den Burg et al. 2005). Cortisol was measured using the manufacturer's protocol of a commercially available kit (Campro Scientific, Veenendaal, The Netherlands).

\section{Statistical analysis}

The differences among groups in the relative expression data were assessed by the non-parametric Mann-Whitney $U$ test. Significance was accepted at $P<0 \cdot 05$. The values are expressed as means \pm s.D.

\section{Results}

We detected basal expression of IL- $1 \beta$ in the NPO. The stress of 24-h restraint upregulated IL-1 $\beta$ expression significantly in this tissue (Fig. 2). In the pituitary PD and PI, IL-1 $\beta$ expression was not detected, either in the control or in stressed fish (not shown). In the PD, mRNA levels of PRL increased almost fourfold following restraint, while $\mathrm{GH}$ expression did not change (Fig. 2). In the head kidney, IL-1 $\beta$ expression significantly increased following 24-h restraint, while expression of TNF- $\alpha$ remained constant in this tissue (Fig. 2). We did not detect the expression of GH and PRL in head kidney (not shown).

To study the expression of the IL-1RI in carp, we used homology cloning based on the zebrafish IL-1RI sequence to obtain the carp sequence. This yielded a 1973 bp IL-1RI sequence encoding a 556 amino acid protein (sequences submitted to EMBL/Genbank database, accession number AJ843873). In line with the tetraploid nature of carp (Uyeno \& Smith 1972), we found two IL-1RI sequences, which differ in seven nucleotides. The deduced amino acid sequence has moderate overall identity with salmon (33\%) and human (23\%) IL-1RI; identity is higher, however, if only the TIR domain is considered (47 and 33\% respectively). To compare the carp sequence with that of other vertebrates, a multiple alignment was made (Fig. 3). Cysteine bonds, immunoglobulin-like regions, the transmembrane segment and the TIR domain are indicated in the figure. A phylogenetic tree was constructed using the neighbour-joining method (Fig. 4). The human, rat and trout IL-1 receptor type II served as outgroup. The mammalian IL-1RI sequences are separated from the piscine sequences by chicken IL-1RI. Within the fish IL-1RI cluster, IL-1RI sequences from carp and salmonids cluster separately. Fugu IL-1RI clusters in proximity to the salmonid

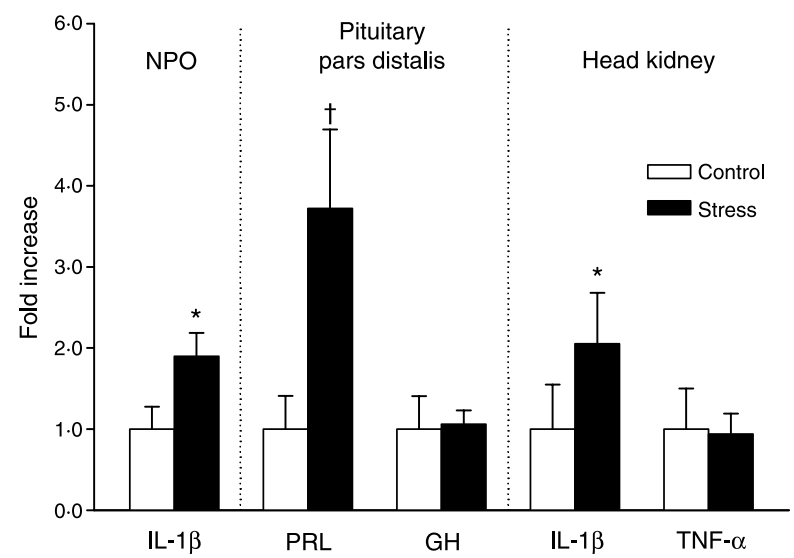

Figure 2 Expression of IL-1 $\beta$ in the NPO, PRL and $\mathrm{GH}$ in the pituitary PD and IL-1 $\beta$ and TNF- $\alpha$ in head kidney in control and stressed fish. Expression was assessed by quantitative RT-PCR and is plotted relative to the expression of $40 \mathrm{~S}$. ${ }^{*} P<0 \cdot 05,{ }^{+} P<0 \cdot 001$. 


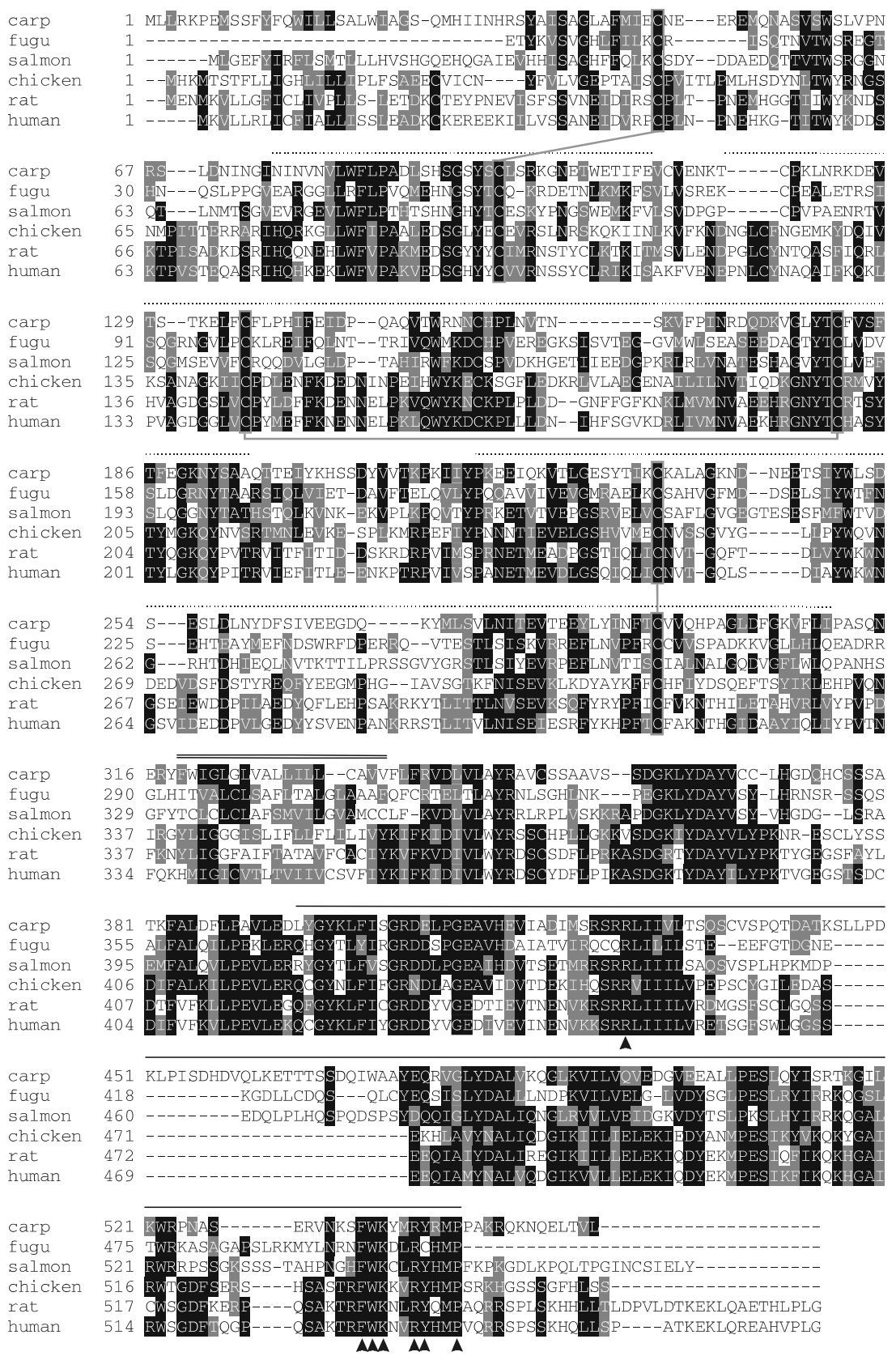

Figure 3 Multiple alignment of IL-1RI sequences of six different vertebrate species, including the newly identified putative carp IL-1RI. Identical amino acids are boxed in black, conservative substitutions in grey. The predicted Ig-like domains are indicated by dotted lines $(\cdots)$, the transmembrane region with double lines $(=)$ and the TIR domain by a single black line $(-)$ displayed above the sequences. Disulphide bonds are indicated by grey lines that connect cysteine residues. Amino acids involved in signal transduction are indicated by arrowheads $(\boldsymbol{\Delta})$. The Fugu sequence was retrieved by BLAST searching of its complete genome at the Ensembl genome browser (http://www.ensembl.org). Accession numbers: carp, AJ843873; human, P14778; rat, Q02955; chicken, AAA48924; salmon, CAC83729; Fugu, SINFRUP00000131701. 


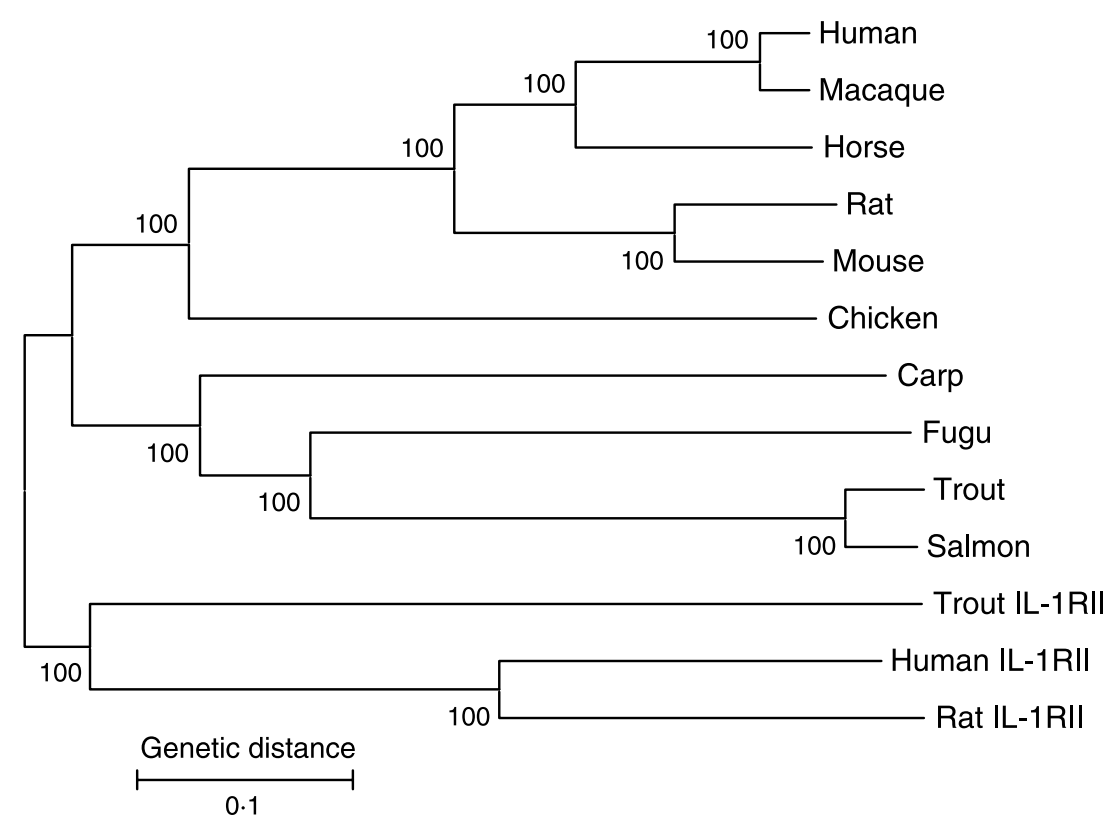

Figure 4 Phylogenetic tree of IL-1RI sequences constructed using the neighbour-joining method. Numbers at branch nodes represent the confidence levels of 1000 bootstrap replications. The human, rat and trout IL-1R type II (IL-1RII) served as outgroup. Accession numbers as in Fig. 3. Additional accession numbers: macaque, AAR88996; horse, BAA83730; mouse, P13504; trout, CAC82935; human IL-1RII, P27930; rat IL-1RII, P43303; trout IL-1RII, CAC19715.

sequences, which resembles established patterns of piscine evolution.

The expression of IL-1RI was found in hypothalamus, both parts of the pituitary gland as well as in head kidney. Hypothalamic IL-1RI expression was not affected following restraint (Fig. 5). In the pituitary PI, restraint induced a significant increase in expression of IL-1RI (Fig. 6A), while expression in the PD remained constant (Fig. 6B). As shown in Fig. 7A, IL-1RI expression in head kidney also significantly increased following restraint. Four hours in vitro stimulation of isolated head kidney macrophages with ConA, LPS and PMA had no effect on expression of IL-1RI (Fig. 7B).

To investigate a functional role for this receptor in the pituitary gland and head kidney, an in vitro superfusion experiment was performed (Fig. 8). Tissues were stimulated with recombinant carp IL-1 $\beta$; TRH and ACTH served as controls for tissue responsiveness of PI and head kidney respectively. In the PI, IL- $1 \beta$ induced a stimulation of $\alpha-\mathrm{MSH}$ and $\mathrm{N}-\mathrm{Ac} \beta$-endorphin release; the stimulation of $\mathrm{N}-\mathrm{Ac} \beta$-endorphin was more profound than that of $\alpha$-MSH (Fig. 8A). In the head kidney, stimulation with IL-1 $\beta$ had no detectable effect on cortisol release (Fig. $8 \mathrm{~B}$ ). Both tissues responded predictably to stimulation with TRH and ACTH. The stress of 24-h restraint induced elevated plasma $\alpha-\mathrm{MSH}$ and N-Ac $\beta$-endorphin levels (Fig. 9).

\section{Discussion}

This study provides four new major observations with regards to the role of IL- $1 \beta$ in the activation of the HPI-axis:

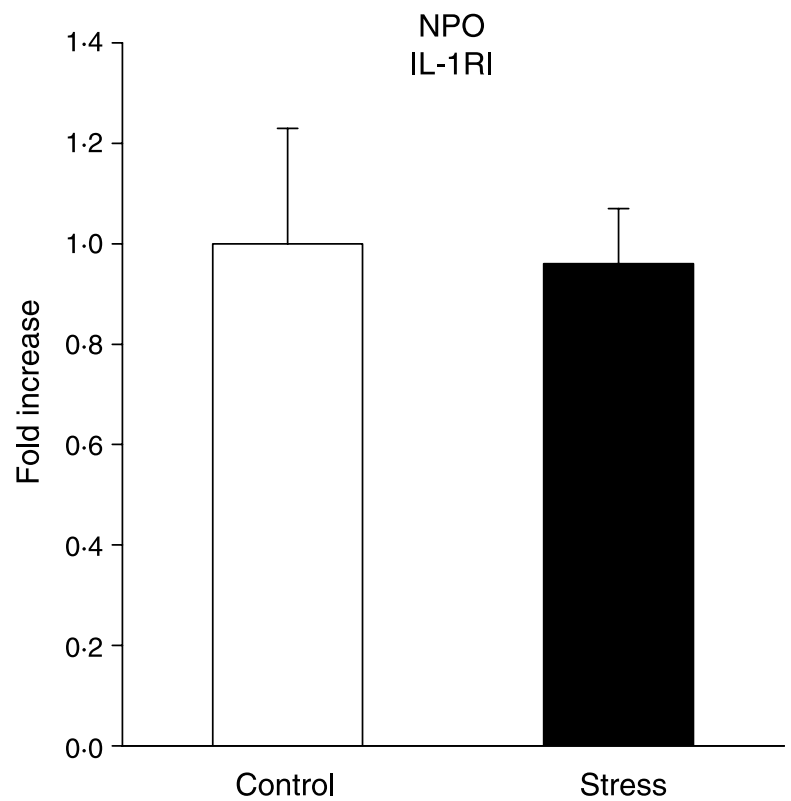

Figure 5 Expression of IL-1RI relative to $40 \mathrm{~S}$ in NPO of control and stressed fish. 

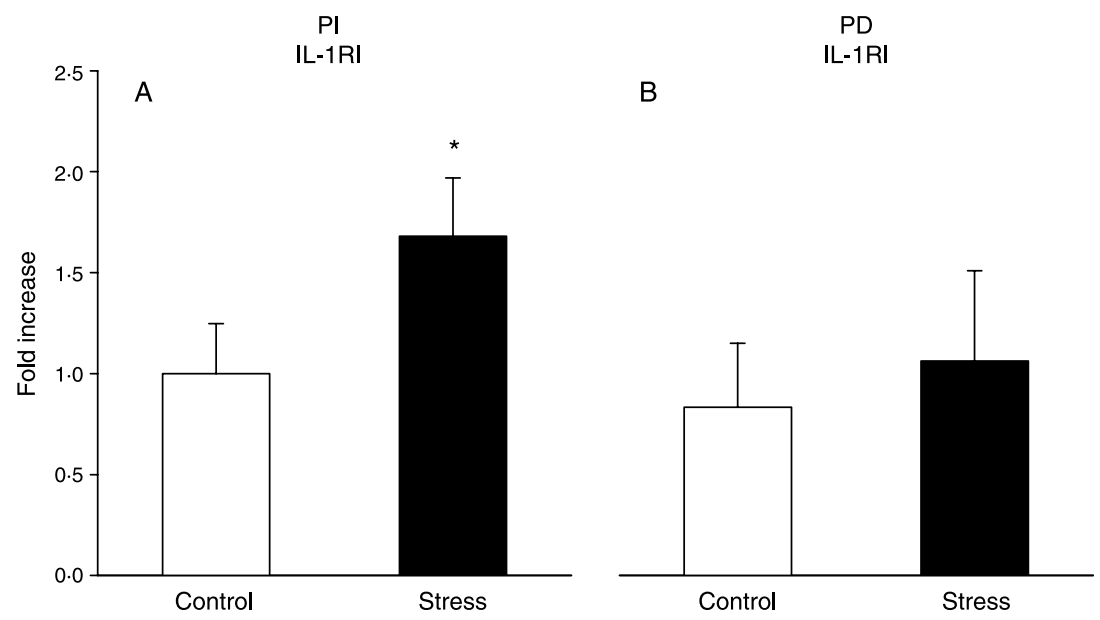

Figure 6 Expression of IL-1RI relative to $40 \mathrm{~S}$ in pituitary (A) PI and (B) PD in control and stressed carp. ${ }^{*} P<0 \cdot 05$.
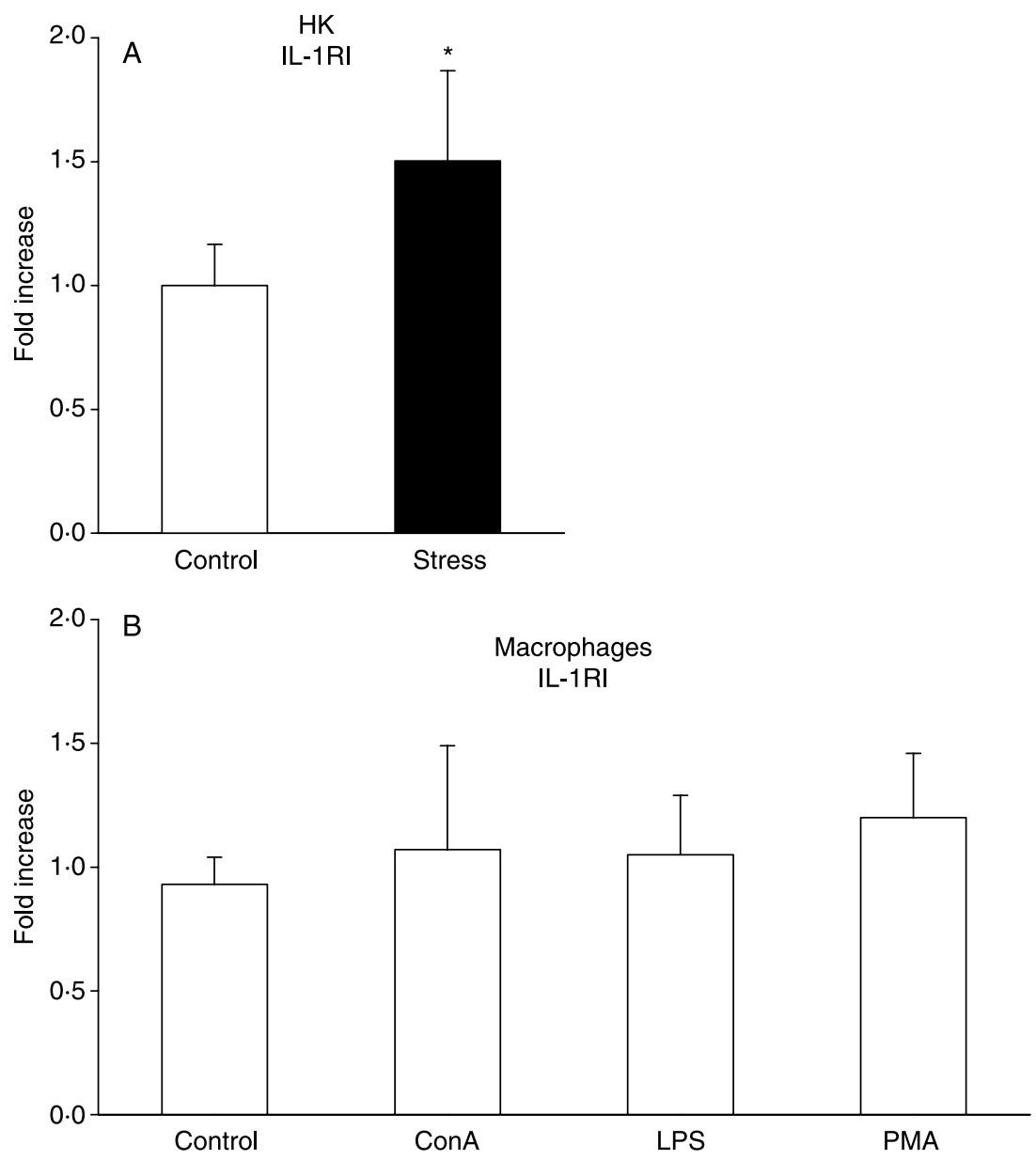

Figure 7 (A) Expression of IL-1RI relative to 40S in head kidneys (HK) of control and stressed fish. (B) IL-1RI expression in head kidney macrophages that were in vitro exposed to ConA, LPS and PMA. ${ }^{*} P<0 \cdot 05$. 

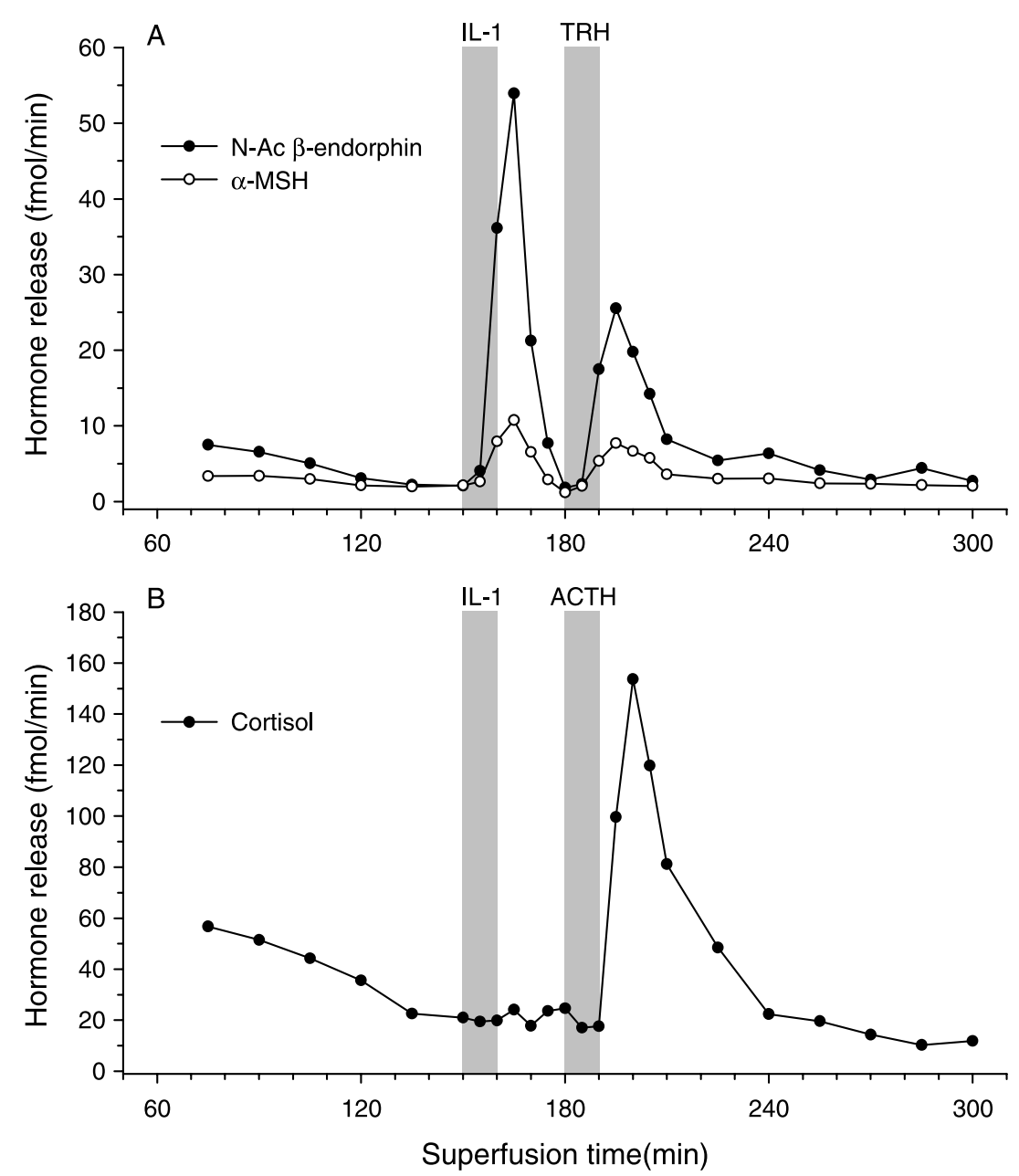

Figure 8 (A) In vitro release of $\alpha-\mathrm{MSH}$ and $\mathrm{N}$-Ac $\beta$-endorphin from pituitary $\mathrm{PI}$ in a superfusion setup. Tissues were successively stimulated with $100 \mathrm{ng} / \mathrm{ml}\left(5 \cdot 3 \times 10^{-9} \mathrm{M}\right)$ recombinant carp interleukin- $1 \beta$ and $1 \times 10^{-7} \mathrm{MTRH}$ as indicated by the shaded bars. (B) In vitro cortisol release by superfused head kidneys stimulated with $100 \mathrm{ng} / \mathrm{ml}$ recombinant carp interleukin- $1 \beta$ and $5 \times 10^{-8} \mathrm{M}$ ACTH respectively, as indicated by shaded bars.

(i) hypothalamic expression of IL-1 $\beta$, which is constitutively expressed, is upregulated during acute stress; (ii) IL-1RI expression is upregulated in head kidney and pituitary PI following restraint; (iii) recombinant carp IL-1 $\beta$ stimulates the in vitro release of $\alpha$-MSH and $\beta$-endorphin from the pituitary PI. From these three findings combined, we propose that during acute stress, IL- $1 \beta$ signalling in the HPI-axis becomes more sensitive by enhanced expression of both ligand and receptor; (iv) the increased expression levels of IL- $1 \beta$ and IL-1RI in head kidney during acute stress indicate that the immune status is altered. These findings will be discussed separately.

IL-1 $\beta$ takes a key position in the innate immune and inflammatory response (Dinarello 1997, Secombes et al. 1999). We subjected fish to $24-\mathrm{h}$ restraint to assess IL-1 $\beta$ expression levels during enhanced HPI-axis activity. As

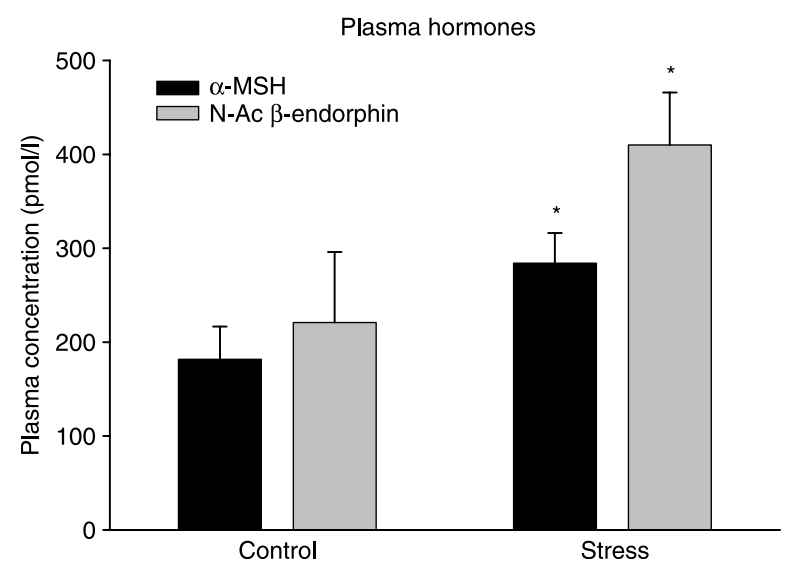

Figure 9 Plasma concentrations of $\alpha-\mathrm{MSH}$ and $\mathrm{N}$-Ac $\beta$-endorphin in control and $24-\mathrm{h}$ restrained fish as determined by RIA. ${ }^{*} P<0 \cdot 05$. 
published earlier, these fish were indeed stressed, as judged by markedly increased plasma cortisol $(176 \pm 133 \mathrm{nM}$ in controls vs $1319 \pm 211 \mathrm{nM}$ in restrained fish, $P<0 \cdot 001)$ and glucose levels $(2 \cdot 56 \pm 0.46 \mathrm{mM}$ in controls vs $9 \cdot 22 \pm 1.48 \mathrm{mM}$ in restrained fish, $P<0 \cdot 001$; Metz et al. 2004). Following 24-h restraint, we detected a twofold increase of IL- $1 \beta$ expression in head kidney, but not of TNF- $\alpha$, which indicates that stress leads to differential activation of specific immune signals. TNF- $\alpha$ is a well-established pro-inflammatory cytokine in mammals (Goetz et al. 2004) as well as fish (Zou et al. 2003), with effects on differentiation, survival and expression of proinflammatory factors in a variety of immune cells, most notably macrophages.

Expression of IL-1 $\beta$ in non-immune tissues such as the pituitary gland and brain, including hypothalamus, has been documented in both mammals (Shintani et al. 1995) and fish (Engelsma et al. 2001), albeit that expression in the pituitary gland of carp is very low (Engelsma et al. 2001). In mammals, acute stressors induce increased IL-1 $\beta$ mRNA and protein (O'Connor et al. 2003). We did not detect IL-1 $\beta$ expression in the pituitary PD and PI of control or stressed carp. In mammals IL-1 $\beta$ in the hypothalamus is associated with HPAaxis activation (Shintani et al. 1995). Moreover, glucocorticoids inhibit hypothalamic IL-1 $\beta$ expression in rat (Chai et al. 1996), which indicates the presence of a negative feedback mechanism. Similarly to our observations in carp, stress induced a $2 \cdot 5$-fold increase in IL- $1 \beta$ mRNA in the preoptic area of the rat (Tanebe et al. 2000). We, therefore, conclude that hypothalamic IL-1 $\beta$ fulfils a similar function in fish as it does in mammals and that this mechanism is phylogenetically conserved.

To study the targets for IL-1 $\beta$, we cloned and identified a putative carp orthologue of the presumed receptor for IL-1 $\beta$, viz. IL-1RI, which displays moderate amino acid homology with IL-1RI sequences of other vertebrate species. Although we realise that we have not considered the ability of the carp IL-1RI to actually bind IL- $1 \beta$ and therefore can only call it a putative IL-1RI, we take the following observations to suggest that the gene cloned indeed represents the IL-1RI orthologue: (1) protein structure resembles the characteristics of the IL-1 receptor family, which include extracellular immunoglobulin-like domains and a cytoplasmic TIR domain; (2) all seven amino acids that have been reported essential for signalling (Heguy et al. 1992), are conserved in the carp sequence; (3) in a neighbour-joining phylogenetic tree, as well as in a maximum parsimony tree, the carp IL-1RI sequence consistently clusters within the type I receptor clade of other fish species, which further confirms its identity as IL-1RI. Interestingly, in salmon, both the constitutive and LPS-stimulated expression profiles of this receptor resemble that of the mammalian IL-1RI and this suggests an analogous function (Subramaniam et al. 2002, Huising et al. 2004a).

The expression of IL-1RI in head kidney macrophages was not influenced by $4-\mathrm{h}$ in vitro exposure to ConA, LPS and PMA. In Atlantic salmon, IL-1RI expression was increased in head kidney following systemic LPS treatment (Subramaniam et al. 2002). In our study, the stress of 24-h restraint induced an increase in IL-1RI expression in head kidney as well as in the pituitary PI; expression in the NPO and PD was unaffected. This tempts us to speculate that during stress, the role of IL- $1 \beta$ peripherally in the immune response as well as centrally in the activation of the HPI-axis, is crucial, as in both these systems expression levels of the signal as well as the receptor increase. Although we have no insight into the kinetics of altered expression levels, these observations seem to contrast with classical negative feedback loop situations. For example, during stress the expression of $\mathrm{CRH}$ in the $\mathrm{NPO}$ is upregulated, while its receptor in the pituitary gland is downregulated (Huising et al. 2004b). We cannot, at present, exclude the possibility that our observations on altered expression levels are a result of stress-induced redistribution of immune cells (Huising et al. 2003b).

A role for IL- $1 \beta$ in the activation of the HPI-axis is further corroborated by our observation that recombinant IL-1 $\beta$ is a very potent stimulator of $\alpha-\mathrm{MSH}$ and $\mathrm{N}-\mathrm{Ac} \beta$-endorphin release from the pituitary PI in vitro. Strikingly, N-Ac $\beta$-endorphin release was more profoundly stimulated than $\alpha-\mathrm{MSH}$ release. Although these peptides are derived from the same precursor, there is evidence that their release is not tightly coupled and differential release occurs in carp (Van den Burg et al. 2005). It must be noted though that we here present only a single experiment due to limited availability of recombinant carp IL-1 $\beta$. This is, however, the first observation in fish which directly shows that a cytokine activates a component of the HPI-axis. Holland et al. (2002) suggested such a direct relation, but their suggestion was based on elevated plasma glucose and cortisol levels following injection with IL- $1 \beta$, which to the best of our knowledge could also be an indirect effect. In line with the in vitro response, we observed elevated plasma levels of $\alpha-\mathrm{MSH}$ and $\mathrm{N}-\mathrm{Ac} \beta$-endorphin in vivo, which further strengthens our extrapolation between the superfusion and in vivo stress experiment.

In mammals, IL- $1 \beta$-driven activation of the HPA-axis mainly occurs via stimulation of CRH-producing cells in the hypothalamus (Turnbull \& Rivier 1999). Presently, we cannot measure CRH in carp, but the presence of the IL-1RI in the NPO may suggest that IL- $1 \beta$ directly targets the CRHproducing neurons in carp. IL- $1 \beta$ has been shown to cross the blood-brain barrier (Banks et al. 2002) and may be produced locally. In addition, ACTH-producing cells of the pituitary PD have been documented to be a target for IL-1 $\beta$ in mammals (Kemppainen \& Behrend 1998, Prickett et al. 2000). In our in vitro study, we considered only the melanotrope cells of the pituitary gland, which apparently are a target for IL- $1 \beta$. We take the observation that IL- $1 \beta$ did not evoke a rise in cortisol release from superfused head kidney to conclude that IL-1RI is not present on interrenal cells but in the haematopoietic tissue, as corroborated by constitutive expression of this receptor in isolated carp head kidney macrophages (Engelsma et al. 2001; this study). 
A 24-h restraint induced a significant decrease in plasma sodium levels from 115 to $97.5 \mathrm{mM}$ (Metz et al. 2004). The same fish were used in this study to assess expression of GH and PRL in the pituitary PD. These cytokines are involved in osmoregulation (Sakamoto et al. 1997) and also in the modulation of immune responses (Yada et al. 2002). While GH expression was unaffected, PRL mRNA levels were greatly enhanced in the present study. The hyponatraemia observed may have led to upregulation of the $P R L$ gene (McCormick 1995). Regarding the role of PRL and GH in the immune system, it has been shown that PRL prevents cortisol-induced apoptosis of in vitro cultured leukocytes in rainbow trout (Yada et al. 2004), with GH having no effect. These observations provide another example whereby stress induces a differential and specific signal to handle the imminent threats of stress.

Earlier, Weyts et al. $(1998 a, b)$ have shown that cortisol, end product of the HPI-axis, affects the immune system; it induces apoptosis in activated B-lymphocytes, while neutrophilic granulocytes, an important source of IL-1 $\beta$, are rescued from apoptosis. In this study, we have shown that the cytokine IL-1 $\beta$ affects the activity of the HPI-axis and that in turn, expression profiles of genes encoding IL-1 $\beta$ and its receptor are modified during acute stress such that the responsiveness of the HPI-axis for IL-1 $\beta$ seems modulated during acute stress. The present study provides further evidence for bi-directional communication of the HPI-axis and the immune system in fish.

\section{Acknowledgements}

The authors are grateful to Mrs Jessica van Schijndel for technical assistance and $\mathrm{Mr}$ Tom Spanings for excellent organisation of fish husbandry and experimental setup. Dr J Kwang (Laboratory of Animal Health Biotechnology, National University of Singapore) is acknowledged for providing recombinant carp IL-1 $\beta$. This study was partially financed by the Dutch Research Council (NWO-ALW), project number $805-46-033$. The authors declare that there is no conflict of interest that would prejudice the impartiality of this scientific work.

\section{References}

Arnold RE \& Rice CD 2000 Channel catfish, Ictalurus punctatus, leukocytes secrete immunoreactive adrenal corticotropin hormone (ACTH). Fish Physiology and Biochemistry 22 303-310.

Baigent SM 2001 Peripheral corticotropin-releasing hormone and urocortin in the control of the immune response. Peptides 22 809-820.

Banks WA, Farr SA \& Morley JE 2002 Entry of blood-borne cytokines into the central nervous system: effects on cognitive processes. Neuroimmunomodulation 10 319-327.

Casadio R, Frigimelica E, Bossu P, Neumann D, Martin MU, Tagliabue A \& Boraschi D 2001 Model of interaction of the IL-1 receptor accessory protein IL-1RAcP with the IL-1beta/IL-1RI complex. FEBS Letters 499 65-68.
Chai Z, Alheim K, Lundkvist J, Gatti S \& Bartfai T 1996 Subchronic glucocorticoid pretreatment reversibly attenuates IL-beta induced fever in rats; IL-6 mRNA is elevated while IL-1 alpha and IL-1 beta mRNAs are suppressed, in the CNS. Cytokine 8 227-237.

Dinarello CA 1997 Interleukin-1. Cytokine and Growth Factor Reviews 8 253-265.

Dunn AJ 2000 Cytokine activation of the HPA axis. Annals of the New York Academy of Sciences 917 608-617.

Dunne A \& O'Neill LAJ 2003 The interleukin-1 receptor/Toll-like receptor superfamily: signal transduction and host defense. Science STKE 171 re3.

Engelsma MY, Stet RJ, Schipper H \& Verburg-van Kemenade BM 2001 Regulation of interleukin 1 beta RNA expression in the common carp Cyprinus carpio L. Developmental and Comparative Immunology 25 195-203.

Engelsma MY, Huising MO, van Muiswinkel WB, Flik G, Kwang J, Savelkoul HF \& Verburg van Kemenade BM 2002 Neuroendocrine-immune interactions in fish: a role for interleukin-1. Veterinary Immunology and Immunopathology 87 467-479.

Gallo VP \& Civinini A 2003 Survey of the adrenal homolog in teleosts. Internation Reviews of Cytology 230 89-187.

Goetz FW, Planas JV \& MacKenzie S 2004 Tumor necrosis factors. Developmental and Comparative Immunology 28 487-497.

Harris J \& Bird DJ 2000 Modulation of the fish immune system by hormones. Veterinary Immunology and Immunopathology 77 163-176.

Heguy A, Baldari CT, Macchia G, Telford JL \& Melli M 1992 Amino acids conserved in interleukin-1 receptors (IL-1Rs) and the Drosophila toll protein are essential for IL-1R signal transduction. Journal of Biological Chemistry 267 2605-2609.

Holland JW, Pottinger TG, Cunningham C \& Secombes CJ 2000 Sequencing and expression analysis of the type I interleukin-1 receptor gene. $E M B L$ Accession Number AJ295296. 295291.

Holland JW, Pottinger TG \& Secombes CJ 2002 Recombinant interleukin-1 beta activates the hypothalamic-pituitary-interrenal axis in rainbow trout, Oncorhynchus mykiss. Journal of Endocrinology 175 261-267.

Huising MO, Stet RJ, Kruiswijk CP, Savelkoul HF \& Verburg-van Kemenade BML 2003a Molecular evolution of CXC chemokines: extant CXC chemokines originate from the CNS. Trends in Immunology 24 307-313.

Huising MO, Guichelaar T, Hoek C, Verburg-van Kemenade BML, Flik G, Savelkoul HF \& Rombout JH $2003 b$ Increased efficacy of immersion vaccination in fish with hyperosmotic pretreatment. Vacine 21 4178-4193.

Huising MO, Stet RJ, Savelkoul HF \& Verburg-van Kemenade BML 2004a The molecular evolution of the interleukin-1 family of cytokines; IL-18 in teleost fish. Developmental and Comparative Immunology 28 395-413.

Huising MO, Metz JR, van Schooten C, Taverne Thiele AJ, Hermsen T, Verburg-van Kemenade BML \& Flik G $2004 b$ Structural characterisation of a cyprinid (Cyprinus carpio L.) CRH, CRH-BP and CRH-R1, and the role of these proteins in the acute stress response. Journal of Molecular Endocrinology 32 627-648.

Kemppainen RJ \& Behrend EN 1998 Enhancement of secretagogue-induced adrenocorticotropic hormone release from cultured sheep anterior pituitary cells by recombinant ovine interleukin-1. American Journal of Veterinary Research 59 107-110.

Kumar S, Tamura K, Jakobsen IB \& Nei M 2001 MEGA2: molecular evolutionary genetics analysis software. Bioinformatics 17 1244-1245.

Lyons PD \& Blalock JE 1997 Pro-opiomelanocortin gene expression and protein processing in rat mononuclear leukocytes. Journal of Neuroimmunology 78 47-56.

McCormick SD 1995 Hormonal control of gill $\mathrm{Na}^{+}, \mathrm{K}^{+}$-ATPase and chloride cell function. In Fish Physiology, pp 285-315. Eds CM Wood \& TJ Shuttleworth. New York: Academic Press.

Mastorakis G, Chrousos GP \& Weber JS 1993 Recombinant interleukin-6 activates the hypothalamic-pituitary-adrenal axis in humans. Journal of Clinical Endocrinology and Metabolism 77 1690-1694.

Metz JR, Huising MO, Meek J, Taverne Thiele AJ, Wendelaar Bonga SE \& Flik G 2004 Localization, expression and control of adrenocorticotropic hormone in the nucleus preopticus and pituitary gland of common carp (Cyprinus carpio L.). Journal of Endocrinology 182 23-31. 
O'Connor KA, Johnson JD, Hansen MK, Wieseler Frank JL, Maksimova E, Watkins LR \& Maier SF 2003 Peripheral and central proinflammatory cytokine response to a severe acute stressor. Brain Research 991 123-132.

Ottaviani E, Franchini A \& Franceschi C 1995 Evidence for the presence of immunoreactive POMC-derived peptides and cytokines in the thymus of the goldfish (Carassius c. auratus). Histochemical Journal 27 597-601.

Ottaviani E, Franchini A \& Franceschi C 1998 Presence of immunoreactive corticotropin-releasing hormone and cortisol molecules in invertebrate haemocytes and lower and higher vertebrate thymus. Histochemical Journal 30 61-67.

Pfaffl MW 2001 A new mathematical model for relative quantification in realtime RT-PCR. Nucleic Acids Research 29 e45.

Prickett TCR, Inder WJ, Evans MJ \& Donald RA 2000 Interleukin-1 potentiates basal and AVP-stimulated ACTH secretion in vitro - the role of CRH pre-incubation. Hormone and Metabolic Research 32 350-354.

Saitou N \& Nei M 1987 The neighbor-joining method: a new method for reconstructing phylogenetic trees. Molecular Biology and Evolution 4 $406-425$.

Sakamoto T, Shepherd BS, Madsen SS, Nishioka RS, Siharath K, Richman NH, Bern HA \& Grau EG 1997 Osmoregulatory actions of growth hormone and prolactin in an advanced teleost. General and Comparative Endocrinology 106 95-101.

Secombes CJ, Bird S, Cunningham C \& Zou J 1999 Interleukin-1 in fish. Fish and Shellfish Immunology 9 335-343.

Shintani F, Nakaki T, Kanba S, Kato R \& Asai M 1995 Role of interleukin-1 in stress responses. A putative neurotransmitter. Molecular Neurobiology $\mathbf{1 0}$ $47-71$.

Sims JE 2002 IL-1 and IL-18 receptors, and their extended family. Current Opinion in Immunology 14 117-122.

Sprang SR \& Bazan JF 1993 Cytokine structural taxonomy and mechanisms of receptor engagement. Current Opinion in Structural Biology 3 815-827.

Subramaniam S, Stansberg C, Olsen L, Zou J, Secombes CJ \& Cunningham C 2002 Cloning of a Salmo salar interleukin-1 receptor-like cDNA Developmental and Comparative Immunology 26 415-431.

Subramaniam S, Stansberg C \& Cunningham C 2004 The interleukin-1 receptor family. Developmental and Comparative Immunology 28 415-428.

Takahashi A, Kawauchi H, Mouri T \& Sasaki A 1984 Chemical and immunological characterization of salmon endorphins. General and Comparative Endocrinology 53 381-388.

Tanebe K, Nishijo H, Muraguchi A \& Ono T 2000 Effects of chronic stress on hypothalamic interleukin-1beta, interleukin-2, and gonadotrophinreleasing hormone gene expression in ovariectomized rats. Journal of Neuroendocrinology 12 13-21.

Tran TN, Fryer JN, Lederis K \& Vaudry H 1990 CRF, urotensin I, and sauvagine stimulate the release of POMC-derived peptides from goldfish neurointermediate lobe cells. General and Comparative Endocrinology $\mathbf{7 8}$ 351-360.

Turnbull AV \& Rivier CL 1999 Regulation of the hypothalamic-pituitaryadrenal axis by cytokines: actions and mechanisms of action. Physiological Reviews 79 1-71.

Uyeno T \& Smith GR 1972 Tetraploid origin of the karyotype of catostomid fishes. Science 175 644-646.
Van den Burg EH, Metz JR, Arends RJ, Devreese B, Vandenberghe I, Van Beeumen J, Wendelaar Bonga SE \& Flik G 2001 Identification of betaendorphins in the pituitary gland and blood plasma of the common carp (Cyprinus carpio). Journal of Endocrinology 169 271-280.

Van den Burg EH, Metz JR, Spanings FAT, Wendelaar Bonga SE \& Flik G 2005 Plasma alpha-MSH and acetylated beta-endorphin levels following stress vary according to $\mathrm{CRH}$ sensitivity of the pituitary melanotropes in common carp, Cyprinus carpio. General and Comparative Endocrinology 140 210-221.

Van Zoest ID, Heijmen PS, Cruijsen PMJM \& Jenks BG 1989 Dynamics of background adaptation in Xenopus laevis: role of catecholamines and melanophore-stimulating hormone. General and Comparative Endocrinology 76 19-28.

Verburg-van Kemenade BML, Engelsma MY, Huising MO, Kwang J, van Muiswinkel WB, Saeij JPJ, Metz JR \& Flik G 2001 Crosstalk between the neuro-endocrine and immune system in teleosts. In Perspectives in Comparative Endocrinology: Unity and Diversity, pp 359-367. Eds HJT Goos, RK Rastogi, H Vaudry \& R Pierantoni. Bologna: Monduzzi Editore.

Wendelaar Bonga SE 1997 The stress response in fish. Physiological Reviews $\mathbf{7 7}$ 591-625.

Weyts FAA, Flik G \& Verburg-van Kemenade BML 1998a Cortisol inhibits apoptosis in carp neutrophilic granulocytes. Developmental and Comparative Immunology 22 563-572.

Weyts FAA, Flik G, Rombout JH \& Verburg-van Kemenade BML $1998 b$ Cortisol induces apoptosis in activated B cells, not in other lymphoid cells of the common carp, Cyprinus carpio L. Developmental and Comparative Immunology 22 551-562.

Yada T \& Nakanishi T 2002 Interaction between endocrine and immune systems in fish. Internation Reviews of Cytology 220 35-92.

Yada T, Uchida K, Kajimura S, Azuma T, Hirano T \& Grau EG 2002 Immunomodulatory effects of prolactin and growth hormone in the tilapia, Oreochromis mossambicus. Journal of Endocrinology 173 483-492.

Yada T, Misumi I, Muto K, Azuma T \& Schreck CB 2004 Effects of prolactin and growth hormone on proliferation and survival of cultured trout leucocytes. General and Comparative Endocrinology 136 298-306.

Yin Z \& Kwang J 2000 Carp interleukin-1 beta in the role of an immunoadjuvant. Fish and Shellfish Immunology 10 375-378.

Zou J, Peddie S, Scapigliati G, Zhang Y, Bols NC, Ellis AE \& Secombes CJ 2003 Functional characterisation of the recombinant tumor necrosis factors in rainbow trout, Oncorhynchus mykiss. Developmental and Comparative Immunology 27 813-822.

Received 14 November 2005

Received in final form 22 June 2006

Accepted 30 June 2006

Made available online as an Accepted Preprint 1 August 2006 